\title{
Erken Cumhuriyet Dönemi Tiyatro Oyunlarında Köken ve Medeniyet Miti
}

\section{The Myth of Origin and Civilization in the Early Republican Era Theatre Plays}

\author{
İstek Serhan Erbek $^{1}$ (1)
}

*Bu makale 2019 ylında Istanbul Üniversitesi Sosyal Bilimler Enstitüsü Tiyatro Eleştirmenliği ve Dramaturji Anabilim Dalı́nda tamamladığım "Erken Cumhuriyet Dönemi Tiyatro Oyunlarinda Siyasal Mitler" başıılılı yüksek lisans tezinden hareketle hazırlanmıştır.

'Araştırma Görevlisi, İtanbul Üniversitesi, Edebiyat Fakültesi, Tiyatro Eleştirmenliği ve Dramaturji Bölümü, İstanbul, Türkiye

\section{ORCID: I.S.E. 0000-0001-6007-1888}

\section{Sorumlu yazar/Corresponding author:} Istek Serhan Erbek,

İstanbul Üniversitesi, Edebiyat Fakültesi, Tiyatro Eleştirmenliği ve Dramaturji Bölümü, Istanbul, Türkiye

E-posta/E-mail: serhanerbek@gmail.com

Başvuru/Submitted: 31.05 .2020 Revizyon Talebi/Revision Requested: 05.06.2020

Son Revizyon/Last Revision Received: 15.06.2020

Kabul/Accepted: 19.06 .2020

\section{Atıf/Citation:}

Erbek, Istek Serhan, "Erken Cumhuriyet Dönemi Tiyatro Oyunlarında Köken ve Medeniyet Miti" Tiyatro Eleștirmenliğive Dramaturij Bölümü Dergisi 30, (2020): 17-34.

https://doi.org/10.26650/jtcd.746119

\section{ÖZ}

Bu çalışmada Cumhuriyetin ilanıyla birlikte yeni rejimin kutsal anlatıları haline gelen köken ve medeniyet mitinin, Erken Cumhuriyet Dönemi tiyatro oyunlarındaki izleri görünür kılınmaya çalışılacaktır. Ulus devletlerin inşa süreçlerinde, kolektif kimliğin yaratılmasında ve tarih yazımında önemli bir işlevi olan köken ve medeniyet mitinin, Türk kimliğinin inşa sürecine katkıları tartışılacak ve sanatsal alandaki etkileri ele alınacaktır. Ulus inşa sürecinin, dönemin tiyatro eserlerine nasıl yansıdığı, devlet ve tiyatro arasında kurulan ilişki, ulus devlet ideolojisinin gerekliliği haline gelen köken ve medeniyet mitinin dönemin oyun yazarlarını nasıl etkilediği ve bu yazarların eserlerini oluştururken siyasal mitlere hangi eksende ihtiyaç duydukları oyunlardan örneklerle analiz edilecektir.

Anahtar Kelimeler: Erken Cumhuriyet Dönemi, Siyasal Mitler, Ulus Devlet İdeolojisi, Behçet Kemal Çağlar, Faruk Nafiz Çamlıbel

\section{ABSTRACT}

In this article, traces of the myth of origin and civilization, which became the sacred narratives of the new regime at the time of the proclamation of the Republic, will be revealed through Early Republican Era theatre plays. The article will emphasize the contribution that the myth of origin and civilization made to the process of construction of Turkish identity, as well as the effective part that it played throughout the nation-state building process by its creation of collective identity and historiography as well as its effect on the field of art. Furthermore, this paper will use examples from theatre plays of the period to analyze the reflections of the process of nation-building upon the theatre plays of the era, and to examine the relationship between the state and the theatre as well as the effects of the myth of origin and civilization (a necessity for the nation-state ideology) on the playwrights of that time. In addition, the way in which political myths become a necessity for playwrights will also be analyzed. Keywords: Early Republican Era, Political Myths, Nation State Ideology, Behçet Kemal Çağlar, Faruk Nafiz Çamlıbel 


\section{EXTENDED ABSTRACT}

Nation-states that were built after the French Revolution of the late 18 th century rejected previous traditions and invented many new ones that circulate their ideologies and keep the discourse of the nation alive. These newly invented traditions had an essential function in terms of building national identity and gathering society together. Nation-states create a connection with a certain ethnicity during their construction process, and within that context they start historiography while they connect their origin with that ethnicity, bringing the old heroes and mythologies that belong to the territories on which they are built to light. Narratives about the origin, ancestry, heroism, and civilization rebuilt through the nation-state ideology thus create a legitimate ground for the new political ideology. Anthony D. Smith entitles those narrations as "mythomoteur", and he adds that those narrations are the constructive myths of political unity. Ernst Cassirer calls the narratives as "modern political myths". Smith analyzes constructive political myths into eight categories based on the motifs and elements that occur in the narratives.

With the proclamation of the Republic and the departure from the political and social order of the Ottoman Empire, the construction of an envisaged nation-state began. The envisaged nation-state would be built upon the modal of western public institutions and Mustafa Kemal would be the leader of it. It would be a secular state and the new regime of the state of Turkey would be the Republic. Many different communities belonging to different beliefs and nations existed on the land where the Republic of Turkey was founded. Therefore, it was impossible to refer historically or culturally to only one ethnic culture or community, as the German nation modal does. The comprehensive nature of the French nation modal is more appropriate for the young State of Turkey. The idea of "everybody who calls themselves Turkish, are Turkish" no matter their ethnic origin, culture, or belief, was one of the main building stones of the newly founded Republic. Political myths, that have an essential function through building collective cultural identity, were the solution to this problem. A historiography came into being which proved that Turks had been living on that territory for years. The new state's study of official history (Türk Tarih Tezi), for the construction of origin, corresponds to the myth of ancestry and the myth of origins in time and space that Smith categorizes. Official history (Türk Tarih Tezi) plays an important role in terms of establishing the discourse of Turkish within the new Republic. The main argument of the official history (Türk Tarih Tezi) is that Turks are the Arian race of middle Asia, that they migrated to several places in the world, and that the powerful civilizations in ancient times, such as Sumerians and Hittites that lived in Anatolia, were Turks.

These political myths that maintained their existence in the social sphere during the process of dissemination of the views on national unity and nationalism, created the ideational background of productions in the theatre field. The political myths had the aim of grounding 
public understanding of single party ideology and they took shape in the embodied form of this ideology in the artistic activities of which they were subjects. Various theatre performances that had been performing under the roof of the Turkish Hearths (Türk Ocakları) gained a corporate and systematic feature after the proclamation of the Republic and the establishment of People's Houses (Halkevleri). Besides this, they also became the tool of propaganda of single party ideology.

For the historiography of the single party ideology, it was important to use the myth of origin and civilization as a subject in theatre plays. The founding board that ignored the history of the Ottoman Empire, used theatre to reach the glorious history that began from Middle Asia and reached to the masses, committing the success of the Turkish war of independence to the memories of the people. The recreation of symbolic people for Turkish society such as Atilla and Mete as heroic legendary figures, dressing the events that happened in the Turkish war of independence with surrealistic narrations of bravery, and praising the actions of the new regime became prominent features of the theatre works of the era. Those narrations, which are the political myths of the Republic, could be seen in many theatre plays, which were written in the Early Republican Era. For the reconstruction of the social memory of the single party ideology, the people were presented with a history and identity that they could boast of through works of theatre. In this context, I will try to discover the contribution of Early Republican era theatre art to the process of reconstitution and the relationship between state and theatre through the myth of origin and civilization. I will also try to make visible the effects of this myth on the playwrights of the era with examples from Vehbi Cem Aşkun's Oğuz Destanı, Faruk Nafiz's Akın ve Özyurt, İsmet Ulukut's Sümer Ülkerleri, Behçet Kemal's Çoban plays. 


\section{Giriş}

18. yüzyılın sonlarına doğru gerçekleşen Fransız Devrimi’nden sonra kurulmaya başlayan ulus devletler, kendilerinden önce var olan geleneklerin yerine, kendi ideolojilerini toplumsallaştıracak ve ulus söylemini canlı tutacak birçok gelenek icat etmişlerdir. İcat edilen bu gelenekler ulusal kimliğin inşası ve toplumun biraradalığını sağlamak için önemli bir işleve sahiptirler. Ulus devletler inşa sürecinde bir etnisite ile doğrudan bağ kurmuş ve bu bağlamda kökenlerini, belirlenen etnisiteye dayandırarak tarih yazımına girişmiş ve kuruldukları topraklara ait eski kahramanları ve mitolojileri gün yüzüne çıkarmışlardır. Köken, soy, kahramanlık ve medeniyet temalı bu anlatılar, ulus devlet ideolojisiyle birlikte yeniden kurgulanarak, yeni siyasal ideolojiye meşru bir zemin yaratmışlardır. Anthony D. Smith bu anlatıları "mythomoteur" olarak adlandırır ve bu anlatıların siyasal birliğin kurucu mitleri olduğunu söyler. Ernst Cassirer ise bu anlatıları "modern siyasal mitler"2 olarak adlandırır. Cassirer bu mitlerin yüzyıllar önce yaşanmış hikâyeleri dramatize ederek duygu birliğini sağladıklarının, didaktik ve dramatik olduklarının altını çizer.

Siyasal mitlerde var olan anlatılar yeni toplumsal ve siyasal düzenin bir uzantısı olarak şekillenir. Modern siyasal mitlerin hepsinde öğretici bir unsur vardır. Ulus devletlerin tarih yazımı için mitlerin didaktik ve duygusal olması gerekir. Bu mitler ulusun duygu birliğini sağlayarak, öğretici anlatılarla yeniden inşanın temelini oluştururlar. Smith, ulus devletlerin inşa sürecinde siyasal mitlerin önemini ve işlevini şöyle açıklar;

Önemlidir, çünkü bize 'kim olduğumuzu'öğretmeye yardımcı olur ve kuşaklar boyunca geriye yayllı bizi atalarımıza ve kökenlerimize bağlayan zincirde bir halka olduğumuz hissini verir. Вu önemlidir, çünkü eğer biz 'kendi kendimizi keşfetmek' istiyorsak, bize 'nerede olduğumuz'u ve 'kim olmamı gerektiği'ni ögretmeye yardımcı olur. Topluluğun hayatındaki geçmiş dönemlerin dramalarını ve atmosferini naklederek, atalarımızın zamanlarını ve hayatlarını 'tekrar canlandırır' ve bizi 'topluluğun kaderi'nin bir parçası yapar. ${ }^{3}$

Smith'in sözlerinden de anlaşıldığı gibi insanların ulusun bir parçası haline gelmeleri, yaşayacakları toplumsal ve siyasal düzeni anlamaları ve içselleştirmeleri için siyasal mitler önemli bir olgudur. İnsanlar yurttaşı oldukları devletin gücünü, geçmişini ve geleceğini görmek isterler ve devletler bu güveni mitler aracılığıyla sağlar. Smith, kurucu siyasal mitleri anlatılarındaki çeşitli motifler ve unsurlar üzerinden sekiz başlıkta kategorize eder;

1) zamandaki başlangıç miti; yani topluluğun ne zaman 'doğduğu';

2) mekândaki 'başlangıç miti; yani topluluğun nerede 'doğduğu';

3) soy miti; yani kim bizi doğurdu ve nasıl onun soyundan geldik;

1 Anthony D. Smith, Ulusların Etnik Kökeni, çev. Hülya Kendir, Sonay Bayramoğlu (Ankara: Dost Kitabevi Yayınları, 2002).

2 Ernst Cassirer, Devlet Efsanesi-İnsan Üstüne Bir Deneme, çev. Necla Arat (İstanbul: Say Yayınları, 2005).

3 Smith, Uluslarin Etnik Kökeni, 231-232. 
4) göç miti; yani nereleri aşıp geldik;

5) kurtuluş miti; yani nasıl özgürleştik;

6) altın çă̆ miti; yani nasıl büyük ve kahraman olduk;

7) çöküş miti; yani nasıl bozulduk ve fethedildik/ sürgün edildik;

8) yeniden doğuş miti; yani eski şanlı günlerimize nasıl dönebiliriz. ${ }^{4}$

Bu çalışmada Smith'in sekiz başlıkta incelediği siyasal mitlerden soy miti, zamandaki ve mekandaki başlangıç mitini köken ve medeniyet miti olarak adlandırarak, Cumhuriyet'in kurulmasıyla birlikte yaşanan toplumsal ve siyasal dönüşümde bu mitin izlerini arayacağım. Köken ve medeniyet mitinin inşa sürecine katkılarını ve kültürel alana etkilerini tartışacağım. Bu bağlamda Erken Cumhuriyet Dönemi tiyatro sanatının bu inşa sürecine katkılarını, devlettiyatro ilişkisini köken ve medeniyet miti üzerinden bulgulamaya ve bu mitin dönemin oyun yazarlarını nasıl etkilediğini oyunlardan örneklerle görünür kılmaya çalışacağım.

\section{Ulus Devletin İnşa Süreci: Köken ve Medeniyet Miti}

Cumhuriyet'in ilanıyla birlikte Osmanlı Devleti'nin siyasal ve toplumsal düzeninden uzaklaşılmış ve tahayyül edilen ulus-devletin inşa süreci başlamıştır. Tahayyül edilen ulus-devlet Batının siyasal ve toplumsal kurumları örnek alınarak Mustafa Kemal önderliğinde inşa edilecek, laik bir devlet kurulacak ve Türkiye Devleti'nin yeni yönetim şekli Cumhuriyet olacaktır. Anayasal ilkeler doğrultusunda hareket eden, laik ve tek bir ulusu temsil eden Batılı devletler, Türkiye Cumhuriyeti'nin tahayyül ettiği yeni yönetim biçimi için bir örnektir. Şerif Mardin ve Türkiye tarihi üzerine çalışma yapan birçok düşünce insanı, Cumhuriyet'in kurulma sürecinde, Türkiye Devleti'nin örnek aldığı inşa sürecinin Fransız ulus modeli olduğunu dile getirir. ${ }^{5}$ Zaman zaman Alman ulus modelinin folklorik ve tarihsel yapısına atıflar yapılsa da Cengiz Aktar Fransız ulus modelinin Türkiye Cumhuriyeti için daha doğru bir tercih olduğunu dile getirir;

Türklük dışında kalan bu kadar farklı din, dil, kültür ve âdeti tek tek dışlayarak yepyeni bir ulusal kimlik altında toplamanın neredeyse fizikî imkansızlı̆̆ldır. Alman ulus modeline karşı Fransız ulus modelinin benimsenmesi bu imkânsızlık karşısında bulunmuş mükemmel bir çözümdür. ${ }^{6}$

Türkiye Cumhuriyeti'nin kurulduğu topraklar üzerinde, çok fazla inanç ve milleti barındıran bir topluluk yaşamaktadır, bu topluluğa dair bir köken arayışı içinde, Alman ulus modelindeki gibi tarihsel ve kültürel olarak tek bir etnik kültüre ve topluluğa referans vermek imkansızdır. Bundan dolayı Fransız ulus modelinin kapsayıcı özelliği yeni kurulan Türk Devleti için daha uygundur. Hangi etnik kökenden, kültürden ya da inançtan olursa olsun "Kendine Türk diyen herkes Türk'tür." fikri kurulan Cumhuriyet'in temel yapı taşlarından biridir. Avrupa'daki

a. e., 245 .

Şerif Mardin, Türkiye ’de Din ve Siyaset (İstanbul: İletişim Yayınları, 1991), 70.

Cengiz Aktar, "Osmanlı Kozmopolitizminden Avrupa Kozmopolitizmine Giden Yolda Ulus Parantezi”, Modern

Türkiye'de Siyasi Düşünce-Milliyetçilik içinde (İstanbul: İletişim Yayınları, 2002), 78. 
diğer ulus devletler gibi Türkiye Cumhuriyeti de inşa sürecini bir etnisiteye tutunarak başlatır. Aktar'ın aksine Ayşe Kadıoğlu Türkiye'deki ulus devlet inşasının, vatandaşlara yeni bir kimlik kurgulanması süreci anlamında, Almanya'dan da Fransa'dan da farklılaştığını ileri sürer;

Türkiye'de ulus-devletin teşekkül etmesi sürecine, millet ve devlet olgularının ortaya çıklşındaki sıralama açısından bakıldiğında: ne Fransa'daki gibi milliyetçilik ve ulus-devlet olgularının eşzamanlı olarak çıkması ne de Almanya'da olduğu gibi milliyetçiliğin ulus-devletten yarım yüzyıl önce ortaya çıkması durumu söz konusudur. Türkiye'de, Almanya'daki gibi “devletini arayan bir millet" değil aksine "milletini arayan bir devlet"ten söz etmek anlamlıdır. Yani Türkler kendiliklerinden örgütlenip bir devlet kurmamışlar ulus-devlet kurulduktan sonra Türk kimliğinin içeriği doldurulmaya çalışılmıştır. ${ }^{7}$

Herhangi bir etnik kimliği çağrıştırmayan ve kendini bir ulus üzerinden resmetmekten kaçınan Osmanlı Devleti'nin tersine, kuruluş süreci itibariyle Türkiye Cumhuriyeti'ni Kadığlu'nun da dediği gibi "milletini arayan bir devlet" olarak nitelemek yanlış olmayacaktır. Mustafa Kemal önderliğindeki kurucu kadroların kamusal ve siyasal alanı yeniden inşası, Avrupa'daki gibi aşağıdan yukarı değil, yukarıdan aşağıya bir dönüştürme projesi olarak ilerlemiştir. Bu dönüştürme projesiyle birlikte insanları yekpare bir vücut haline getirecek ve onlara Osmanlı İmparatorluğu'nu unutturacak yeni bir toplumsal sözleşmeye ihtiyaç vardır. Bu da Barış Ünlü 'nün deyimiyle “Türklük Sözleşmesi”dir. ${ }^{8}$ Ünlü, Osmanlı İmparatorluğu'nun varlığını "Müslümanlık Sözleşmesi” adı altında sürdürdüğünü ancak Cumhuriyet için bunun yeterli olmadığını söyler ve Türklük Sözleşmesi’ne geçişi üç maddeyle açıklar;

Birincisi, kurucular yeni devletin ve toplumun sadece Müslümanlık ortaklı̆̆ında bir arada kalmayacă̆ını; Müslüman milleti içindeki etnik grupların, etnik kültürlerin ve bilinçlerin yok edilmesi gerektiğini düşünüyorlard. Dağılma ve parçalanma olasıliğı böylece bertaraf edilecekti. İkincisi, Mustafa Kemal başta olmak üzere kurucu liderler, 1906'dan sonra İttihat ve Terakki'nin hâkimiyetini ele geçiren Türkçü bir kuşaktan geliyorlardl. Yani birer Türk milliyetçisiydiler. Anadolu kurtarllip yeni bir devlet kurulduktan sonra Türkleştirme projesini hayata geçirdiler. Üçüncüsü, özellikle Mustafa Kemal, bu defa ait olduğu İttihatçı kuşağın aksine, zihninde ikilem barındirmayan radikal bir Batılılaşma ve laiklik taraftartydi. Bu nedenle Müslümanlık Sözleşmesi'nin İslami söylemini devam ettirmesi mümkün değildi. Dolayısıyla Müslümanlık Sözleşmesi'nden Türklük Sözleşmesi'ne geçiş sadece bir Türkçülük adımı değil, aynı zamanda dini milletten seküler ulusa geçişi sembolize eden bir laiklik adımıydı. ${ }^{9}$

Değişen bu toplumsal sözleşmeyle birlikte kurulan yeni devlet bir kimlik problemiyle karş1 karşıyadır. Kolektif kültürel kimliğin oluşumunda önemli bir işleve sahip olan siyasal mitler, bu problemin çözümüdür. Türklük Sözleşmesi’nin bir gerekliliği olarak, Türklerin yüzyıllardır bu topraklarda yaşadıklarını ispatlayan bir tarih yazımına girişilir. Yeni devletin köken kurgusu

7 Ayşe Kadığlu, "Milliyetçilik-Liberalizm Ekseninde Vatandaşlık ve Bireysellik”, Modern Türkiye'de Siyasi Düşünce-Milliyetçilik içinde (İstanbul: İletişim Yayınları, 2002), 287.

8 Barış Ünlü, Türklük Sözleşmesi (Ankara: Dipnot Yayınları, 2018).

9 a. e., 165. 
için yaptığ 1 Türk Tarih Tezi çalışması, Smith'in sekiz başlık olarak kategorize ettiği siyasal mitlerin soy miti ve mekandaki ve zamandaki başlangıç mitine karşılık gelmektedir. Türk Tarih Tezi, Türklük söyleminin yeni Cumhuriyet’te yerleşmesi için önemli bir rol oynar. 1930 yılında Türk Ocaklarına bağlı Türk Tarihi Tahkik Heyeti, Yusuf Akçuraoğlu önderliğinde Türk Tarih Tezi üzerine çalışmalara başlar. Heyette Reşit Galip, Ahmet A ğaoğlu, Afet İnan ve Fuad Köprülü gibi dönemin önemli tarihçileri ve parti ideologları da vardır. Bu heyetin ismi, Türk Ocakları'nın kapanmasıyla birlikte Türk Tarihini Tetkik Cemiyeti olarak değiştirilir. Türk Tarih Tezi'nin temel iddiası Orta Asya'nın aryan ırkı olan Türklerin dünyanın çeşitli yerlere göç ettiği, antik çağdaki büyük medeniyetlerin ve özellikle Anadolu topraklarında yaşamış Sümerler'in ve Hititler'in Türk olduğu iddiasıdır. Hatta dönemin ideologları Yunanlıların bile Türk olduğunu iddia etmişlerdir. ${ }^{10}$ Dönemin İçişleri bakanı Şükrü Kaya’nın sözleri, tek parti ideolojisinin etnisite arayışının, Türkleri medeniyetin kurucu unsuru olmaya kadar götürdügünü göstermektedir; "Zaten insanlık tarihi Türklerle başlamıştır. Türk olmasaydl, belki tarih olmazdl ve muhakkak ki medeniyet de başlamazdl. "11 Türklerin medeniyetlerin kurucu unsuru olduğu düşüncesi, yeni kurulan devletin eskiden beri bu toprakların sahibi olduğu düşüncesine dayanmaktadır. Kurulduğu topraklar üstünde modern Türkiye'nin inşası için, yeni bir toplumsal hafiza yaratmaya çalışan tek parti ideolojisi, siyasal mitlerin kültürel işlevinden yararlanır. Kurucu kadrolar, meşruiyet problemini ortadan kaldırmak için Türk kimliğinin köklerine dönerek, köken ve medeniyet mitini kurgular. Kurulduğu topraklarda köken ve medeniyet miti üzerinden bir geçmiş yaratılır. Uluslaşma sürecinde emekleyen yeni devletin bu iddiaları modernleşme projesi için büyük önem taşımaktadır.

\section{Kültürel Alanın İnşası ve Tiyatro}

Cumhuriyet ideolojisinin toplumsallaşması ve gündelik hayat pratikleri içinde deneyimlenmesi için daha önce de değindiğimiz gibi bir takım kurumsallaşma faaliyetlerine gidilmiştir. Tek parti ideolojisi, halkın toplumsal hayatta gerçekleşen bu dönüşüme uyum sağlaması için çeşitli stratejiler izlemektedir. Yeni ideoloji etrafinda şekillenen Batılı değerlerin yurttaşlar tarafından benimsenmesi için Halkevleri önemli bir konumdadır. Halkevleri aracılığıyla, Cumhuriyet' in siyasal miti haline gelen köken ve medeniyet miti üzerinden milli kültür inşa edilmeye çalışılır. Şehirlerde ve kasabalarda örgütlenen Halkevleri, tek parti ideolojinin kazanımlarının yaygınlaştırıcısı ve yaratılmaya çalışılan toplumsal düzenin düzenleyicisi haline gelir. "Yepyeni bir kültürün yaratılması ve bunun halka mal edilmesi Halkevlerine düşmektedir. "12 Kurucu kadrolara göre modernleşmiş bir devletin en temel unsurlarından biri, kültürel alandaki başarılardır. Bu anlamda, kültürel alanın yeniden inşası sürecinde Halkevlerine büyük iş düşmektedir. Arzu Öztürkmen Halkevleri’nin iki önemli misyonu olduğunu belirtir;

10 Suavi Aydın, Modernleşme ve Milliyetçilik (Ankara: Gündoğan Yayınları, 1993), 229.

11 Aktaran: Cemil Koçak, "Kemalist Milliyetçiliğin Bulanık Suları”, Modern Türkiye’de Siyasi Düşünce-Milliyetçilik (İstanbul: İletişim Yayınları, 2002), 38.

12 Anıl Çeçen, Halkevleri (Ankara: Gündoğan Yayınları, 1990), 205. 
Halkevleri iki önemli misyonla faaliyete geçtiler. Bunlardan ilki Türk Ocakları ve Köycüler Cemiyeti gibi kökleri Jön Türk Devrimine kadar uzanan bir sosyal reform misyonuydu. Diğeri ise yeni devletin Batılılaşma projesini pratiğe geçirecek sanatsal ve kültürel faaliyetleri başlatmak ve yürütmekti. ${ }^{13}$

Halkevleri, faaliyet alanlarına göre ayrılan bölümlerin bir kısmı sosyal reform ile ilgilenirken, bir kısmıysa kültürel ve sanatsal alanın inşası üzerine çalışmaktadır. Yeni devlet için topyekûn seferberlik çağrısı siyasal ve toplumsal alanda olduğu gibi kültürel ve sanatsal alanda da geçerlidir. Anıl Çeçen, bu inşa sürecinde sanatçılara büyük görev düştüğünü söyler;

Hergün kucağında daha genişs ölçüde vatandaşı toplayacak olan Halkevleri ülke çapında gerçek Türk kültürünün yaratıcısı ve yayıcısı olabilecektir. (...) Yeni Türk toplumunun yaratılmasında artık sanatçılar da birer nefer gibi çalışacaklardı. ${ }^{14}$

Yüzyıllardır Osmanlı İmparatorluğu çatısı altında çok kültürlü bir yaşam süren bir toplumda, modern bir Türk kültürü ve sanatı yaratmak kolay değildir. Kültürel ve sanatsal alanın inşası için tıpkı cephede savaşır gibi savaşmak gereklidir. Bu savaşta sanatçıların, Cumhuriyet'in neferleri olarak en ön safta yerlerini almaları gerekir. Sanat alanında, devlet tarafından yapılan kurumsallaşma çalışmaları Halkevleri ile sınırlı kalmaz. Devlet; resim, tiyatro, müzik ve heykel gibi sanatın farklı dallarından sanatçılara mesleki yapılanmalarını tamamlamaları için olanak sağlamaktadır ve Avrupa'dan çeşitli sanatçılar getirerek, kurumsallaşma çalışmalarını hızlandırmaya çalışır. ${ }^{15}$ Kültürel ve sanatsal alandaki bu seferberliğin en temel amacı, tek parti ideolojisinin 1şı̆̆ında milli sanatı ve milli kültürü oluşturmaktır.

Milli birlik ve uluslaşma vurgularının yaygınlaşması ve halk tarafından içselleştirilmesi sürecinde toplumsal alanda varlığını sürdüren siyasal mitler, tiyatro alanında yapılan üretimin üzerinde şekillendiği düşünsel zemini oluşturur. Söz konusu siyasal mitler, tek parti ideolojisinin toplumsal kavrayışını temellendirme amacı taşır ve konusu olduğu sanatsal faaliyetlerde bu ideolojinin vücut bulduğu somut biçimleri alır. Türk Ocakları bünyesinde halihazırda yapılmakta olan çeşitli tiyatro gösterileri, Cumhuriyet'in ilanının ardından Halkevleri'nin kurulmasıyla kurumsal ve sistematik bir nitelik kazanır ve tek parti ideolojisinin propaganda aracı haline gelir. Dönemin tiyatro oyunu yazarlarından Behçet Kemal'in deyimiyle, "Bazı Inkılap hareketlerinin halka tam mâl olması, halkın ruhuna tam sinmesi için, sanatın elinde parlaması, sanatın imbiğinden geçmesi lazımdır."16 Bir diğer oyun yazarı Münir Hayri ise, "inkılâplar devrinde doğan yeni fikirleri yaymak için kullanılan vasıtaların arasında, hâtta başında tiyatro ele alındı. "17 sözüyle dönemin tiyatro anlayışını özetlemektedir. Behçet Kemal

13 Arzu Öztürkmen, Türkiye'de Folklor ve Milliyetçilik (İstanbul, İletişim Yayınları, 1998), 70-71.

14 Çeçen, Halkevleri, 153.

15 Bkz. Fethiye Erbay-Mutlu Erbay, Cumhuriyet Dönemi (1923-1938) Atatürk'ün Sanat Politikası (İstanbul: Boğaziçi Üniversitesi Yayınevi, 2006).

16 Behçet Kemal, "Gönüllü Sanat”, Ülkü Halkevleri Mecmuası 23 (1935), 336.

17 Münür Hayri, “Bugünkü Manasiyle Tiyatro Nedir?”, Ülkü Halkevleri Mecmuası 18 (1934), 434. 
ve Münir Hayri'nin sanata bu bakışı dönemin pek çok tiyatro yazarının ve kurucu kadroların görme biçimini yansıtır. Resmî ideolojinin şekillendirdiği yeni devletin bütün icraatlarının sanat yoluyla yaygınlaşması gerekir. Kurucu kadrolar için tiyatro sanatı ideolojilerini kitleler arasında yaygınlaştırmak için önemli bir araçtır. Halkevleri'nin çalışma kollarından biri olan temsil kolu, resmî ideoloji ile halk arasındaki uzaklığg gidermek için önemli bir işleve sahiptir. Tiyatro yoluyla ulusal birlik yaratılması, halk ve devlet arasındaki uzaklığı giderme hedefi için stratejik bir önem taşımaktadır. Bundan dolayı özellikle Halkevleri bünyesinde gösterilen tiyatrolar ve yazılan eserler Cumhuriyet'in icraatlarını ve ideolojisini anlatmaktadırlar. CHP (Cumhuriyet Halk Partisi) tarafından 1935 yılında yayımlanan, Halkevleri'nin yaptığı çalışmaların anlatıldığı kitapta, tiyatronun milli duygulara seslenmesinin gerekliliği açıkça ifade edilir;

Illk zamanlarda hep tarihî ve millî muayyen mevzular üzerinde duran piyesler yazılmış ve seçilmiş olması, bir tesadüf eseri olmamıştır: halka telkini çok yerinde bir hareket olacak olan tarih tezimizin iyice içe sinmesi ve halk ruhunda kökleşmesi, kurtuluş savaşı hatıra ve heyecanlarını bir def'a daha geriden ve şuurlu bir heyecanla tesbit edilmesi esaslart gözetilmiştir. ${ }^{18}$

Tek parti ideolojisinin tarih yazımında önemli bir yer tutan köken ve medeniyet mitinin tiyatro eserlerine konu olmasına özen gösterilir. Osmanlı İmparatorluğu'nun tarihini yok sayan kurucu kadrolar, Orta Asya'dan başlattığı “şanlı” tarihini kitlelere ulaştırmak ve Kurtuluş Savaşı'nın başarısının hafızalarda kök salması için tiyatroyu kullanır. Dönemin tiyatro eserlerinde Atilla, Mete gibi Türk toplumu için sembol haline gelmiş kişilerin kahraman miti olarak yeniden canlandırılması, Kurtuluş Savaşı sırasında yaşanan olayların gerçeküstü kahramanlık anlatılarıyla süslenmesi ve yeni rejimin icraatlarının övülmesi gibi konular öne çıkar. Cumhuriyet'in siyasal mitleri olan bu anlatılar, Erken Cumhuriyet Dönemi yazılan birçok tiyatro oyununda görülür. Tek parti ideolojisinin toplumsal belleğinin yeniden inşası için tiyatro eserleri aracılığıyla halka, övünç duyacağı bir tarih ve kimlik sunulur. Sefa Şimşek, devletin tiyatroya bakış açısını şöyle tanımlar;

Partinin ve Halkevlerinin tiyatroya yaklaşımı, Türk ırkını ve tarihini tiyatro sanatını ilk geliştiren ve onu öteki milletlere ögreten bir özne olarak algılamaları ve yüceltmeleri doğrultusunda olmuştur. Bu, aslında Türk Tarih Tezinin sanata getirdiği genel bakış açısının tiyatroya uyarlanmış özel bir biçimiydi. ${ }^{19}$

Türk Tarih Tezi bağlamında büyük medeniyetlerin kurucusu ilan edilen Türkler'in, tiyatro sanatında da öncü oldukları iddia edilir. Saim Kerim Kalkan Cumhuriyet Devrinde Tiyatro Hareketleri ve Halkevleri ${ }^{20}$ adlı yazısında Türkler' in dört bin yıl önce Orta Asya'da yaşarken sanat ve tiyatroyu zaten bildiklerini ve icra etmekte olduklarını söyler. Münir Hayri Egeli

18 CHP, Halkevleri 1932-1935: 103 Halkevi Geçen Yıllarda Nasıl Çalıştı (Ankara: 1935), 55-56.

19 Sefa Şimşek, Bir İdeolojik Seferberlik Deneyimi Halkevleri 1932-1951 (İstanbul: Boğaziçi Üniversitesi Yayınevi, 2002), 190.

20 Saim Kerim Kalkan, “Cumhuriyet Devrinde Tiyatro Hareketleri ve Halkevleri” Yeni Türk 71 (1938). 
benzer bir iddiada bulunur. Egeli kuklanın Türk oyunu olduğunu ve Bizans döneminde Orta Asya'dan geldiğini iddia eder. ${ }^{21}$ Egeli'nin bu iddiası Osmanlı Tiyatrosu'nda önemli bir yeri olan Karagöz'ün millileştirilme çabasına bir örnektir. Benzer şekilde Sabri Esat Siyavuşgil de Karagöz'ü millileştirme çabasıyla İstanbul'da Karagöz, Karagöz'de İstanbul adlı bir eser yazmıştır. ${ }^{22}$ Modern Türkiye'nin kendini var edebilmesi için toplumun övünç duyacağı ve kendini güçlü hissedeceği bir geçmiş gerekmektedir. Sevda Şener bu gerekliliğin dönemin tiyatro oyunlarında yer alan öğeler ile yerine getirilmeye çalışıldığını ifade eder;

Halkevleri tiyatro kolları için yazılmış olan bu oyunların, yüzyıllarca kul olarak kendi gücünü görmezden gelmeye zorlanmış olan halka özgüven aşılamak, ulusal değerleri öne çıkarmak amacıyla yazllmış, asal özelliği eğitici ve öğretici olan, didaktik dediğimiz türden oyunlar olduğu görülür. Bu bakımdan bu oyunların konuları ve kişileri, yaşanan gerçeklerden çok, benimsenmiş doğrulardan yola çıkılarak kurgulanmıştır. ${ }^{23}$

Şener'in de belirttiği gibi, Erken Cumhuriyet Dönemi'nde yazılan tiyatro eserlerinde, toplumsal ve siyasal gerçeklikten ziyade, tahayyül edilen Türkiye anlatılır. Dönemin tiyatrosu, Kemalist ideoloji tarafından belirlenen çerçeve içinde, ulusal değerlerin oluşmasına önemli katkı sağlar. Nilgün Firidinoğlu, tek parti ideolojisinin tanımladığı vatandaşlık kavramı ve makbul tiyatro izleyicisi arasında şöyle bir benzerlik kurar;

Dolaylstyla tiyatronun "makbul izleyicisi" ve Cumhuriyetin "makbul vatandaşı" olma hali eş zamanlı bir biçimde ilerliyordu. Her iki durumda da bireyin kendini bir topluluğun parçası olarak hissedebilmesi, bir ayinin ortasında müșterek ameller ve duygularla birlikte hareket edebilmeyi sağlayacak ruhun var edilmesi gerekiyordu. "24

Tiyatronun form olarak halka ulaşma biçiminin kendisi, birlik ve beraberlik duygusunun yaratılması için önemlidir. Tek ülkü etrafında aynı yolda yürüyen insanlar, tiyatro izleme faaliyeti ile yaratılır. Parti devleti de tiyatroya bu anlamda belirgin bir işlev yükler ve bunu yayınlanan eserlerinde "tiyatronun eşsiz telkin kuvveti" olarak tanımlar. Tiyatro tek parti ideolojisinin fikirlerini telkin eden ve bu fikirlerin yurttaşlara ulaşmasını sağlayan önemli bir araçtır.

\section{Tiyatro Oyunlarında Köken ve Medeniyet Miti}

Türk Tarih Tezi gibi mevcut ideolojinin yeniden tarih yazımına hizmet eden kaynaklar, Türkiye toplumunun kökenlerini Orta Asya'da bulur ve toplumun kültürel inşasını yarattığı bu tarihten hareketle şekillendirir. Cumhuriyetin inşa sürecindeki kurucu kadrolar, Orta Asya'daki Türk kimliğine sarılarak, kurulmakta olan devleti ve bu yeni devletin yurttaşlarını

21 Şimşek, Bir İdeolojik Seferberlik Deneyimi Halkevleri 1932-1951, 190.

22 Sabri Esat Siyavuşgil, “İstanbul'da Karagöz, Karagöz’de İstanbul”, Karagöz Kitabı içinde, Der. Sevengül Sönmez (İstanbul: Kitabevi, 2005), 104-118.

23 Sevda Şener, Cumhuriyet'in 75. Yılında Türk Tiyatrosu (İstanbul: Türkiye İş Bankası Kültür Yayınları, 1999$), 89$.

24 Nilgün Firidinoğlu, “Tanzimat’tan Erken Cumhuriyet’e Tiyatro ve Eğitim İlişkisi: Mektep Temsilleri (18961936)", (Doktora Tezi, İstanbul Üniversitesi, 2015), 80. 
yeni bir kimlik üzerinden inşa etmeye çalışırlar. Kurucu kadroların iddiası, devletin üzerine kurulduğu medeniyetin, Osmanlı Devleti kurulmadan yüzyıllar önce mevcut sınırlarda kurulan Türkiye Cumhuriyeti topraklarında varlığını sürdürdüğüdür. Bu iddianın pekiştirilmesi için, yeni kurulan ulus devlet ile Orta Asya coğrafyası ve tarihi arasında önemli bir ilişki kurulur ve bunun gerek tarih yazımında gerekse sanat alanında her firsatta altı çizilir. Smith kurulmakta olan devlet için bu köken yaratma çabasının önemini şu sözlerle açıklar;

Modern milletlerin bir başka antik yüzü daha vardır; coğrafi konumları. İddia odur ki olmaları gereken yerdedirler, zira coğrafyanın belirli yerleriyle çok uzun süre ilişkili olmuşlardır. "Milletler derin kökler salmışlardır." Kökler iddia olunduğu kadar derin olmasa da,basitçe uluslararası kabule değil kollektif iç güvenliğin ve nesli sürdürmenin çok daha temelli hedefleri bakımından sunulmuş bir iddia olmalıdır bu. ${ }^{25}$

Kurucu kadrolar, Türklerin yüzyıllar önce Orta Asya'dan Anadolu’ya geldiğini ve bu topraklarda kökleşmiş olduklarını ispat etmeye çalışırlar. Smith'in de belirttiği gibi bu durum toplumsal alanda kolektif kimlik yaratımı için büyük önem taşır. Yaratılmak istenen Türk kimliği, Osmanlı Devleti’nden ve İslam kültüründen uzaklaşarak Orta Asya kültürüyle ilişkilendirilir. Türk kimliği etrafında inşa edilen ulus devlet için, Orta Asya Türkleri ve kültürüyle kurulan bu ilişki Cumhuriyet' in köken ve medeniyet miti haline gelir. Halkevleri'nin yayın organı olan Ülkü dergisinde çeşitli tarihçiler tarafından düzenli olarak Orta Asya Türkleri ve Türklerin önemli medeniyetlerin kurucusu olduğu iddiaları üzerine yazılar yazılır. Dönemin tarihçilerinden Hüseyin Namık Orkun Ülkü dergisinin 1935 yılında yayınlanan bütün sayılarında Orta Asya Türkleri ile ilgili yazı dizisi başlatmış ve Uygurca dilinde yazılmış Oğuz Destanı'nın çevirisini yaparak, dergide yayınlatmıştır. ${ }^{26}$ Köken ve medeniyet mitinin izlerini dergilerin yanında, Erken Cumhuriyet Dönemi'nde yazılan tiyatro oyunlarında da görmek mümkündür. Bu bağlamda, Erken Cumhuriyet Dönemi'nde yazılan tiyatro oyunlarında köken ve medeniyet mitini Vehbi Cem Aşkun'un Oğuz Destant ${ }^{27}$, Faruk Nafiz'in $A k \imath^{28}$ ve Özyurt ${ }^{29}$, İsmet Ulukut'un Sümer $\ddot{U} l k e r l e r i{ }^{30}$, Behçet Kemal'in Çoban ${ }^{31}$ oyunları üzerinden ele alacağım.

Aşkun 1935 yılında yazdığı Oğuz Destanı oyununun amacını eserin ilk sayfasında açıkça dile getirir; "Gençliğe ve çocuklarımıza tarihsel bir olguyu imsilsel bir ders özlüğünde vererek sevdirmek." ve "Onların yüreklerinde ulusal bir heyecan uyandırmaktır. "32 Aşkun yazdığ tiyatro oyunu için, temel amacının Cumhuriyet' in tarih yazımı bağlamında, tarihsel bir olguyu temsil etmek ve inşa edilmeye çalışılan milli kimliğe katkı sunmak olduğunu açıkça söyler.

25 Anthony D. Smith, Milli Kimlik, çev. Bahadır Sina Şener (İstanbul: İletişim Yayınları, 2016), 115.

26 Hüseyin Namık Orkun, "Bir Oğuz Efsanesi”, Ülkü Halkevleri Mecmuası 34 (1935), 267.

27 Vehbi Cem Aşkun, Oğuz Destanı (İstanbul: Milli Mecmua Matbaası, 1935).

28 Faruk Nafiz, Akın (İstanbul: Devlet Matbaas1, 1932).

29 Faruk Nafiz, Özyurt (Ankara: Hakimiyeti Milliye Matbaası, 1932).

30 A. İsmet, Sümer Ülkerleri (İstanbul: Ülkü Kitaphanesi, 1934).

31 Behçet Kemal, Çoban (Ankara: Hakimiyeti Milliye Matbaası, 1933).

32 Așkun, Oğuz Destanı, 3. 
Oyun, Çocuk'un Türklüğe övgülerle dolu bir şiir okuduğu prolog sahnesiyle başlar. Oğuz ormandadır. Karşısında bir kadın belirir. Tanrı tarafından Oğuz'a yollanmıştır. Oğuz’un bu kadından altı çocuğu olur. Akın için çocuklarından üçünü doğuya üçünü batıya yollar. Çocuklar döner. Kazandıkları zaferleri babalarına anlatırlar. Oğuz, anayurdu doğu ve batı olarak ikiye böler. Çocuklarına kazandıkları toprakların başına geçmelerini söyler. Destan biter. Cumhuriyet dönemi Türkiye'sinden iki çocuk tekrar sahneye gelir. İkinci Oğuz’un Atatürk olduğunu ve Türk soyunu anlatan bir şiir okurlar ve oyun biter. Aşkun'un, bu destanın başına ve sonuna koyduğu çocukların şiir okuduğu iki sahne, yeni kurulan Türkiye Cumhuriyeti'nin köken kurgusuna hizmet etmektedir. Yeni kurulan ulus devletin nereden geldiği çocuk tarafından ön oyunda dile getirilen şu sözlerle anlatır;

(...) Dinleyin bir parçacık, düşünün ki şimdi biz,

Hangi soy, hangi soptan gelmişiz, kimiz, neyiz,

Anlatmak istiyorum, dilim döndüğ̈̈ kadar,

Koç yiğitler kaynă̆ı Türklü̆ğü size dostlar.

Ünlü soydan olan biz, Anadolu türkleri,

Sayılsakta nekadar, Kayıhanın boyundan,

Atamız Oğuz handır geldik onun soyundan. ${ }^{33}$

Aşkun, Cumhuriyetin ilk yıllarında sürmekte olan "biz kimiz" tartışmasını oyunun ilk sahnesinde yer alan alıntıdaki sözlerle noktalar. Türk kimliği, kökenleri ve tarihte yeri belli olan bir medeniyet olarak, tek parti ideolojisinin siyasal miti haline gelir ve bir övünç kaynağına dönüşür. Oğuz Destanı'nın mitolojik ve doğaüstü öyküsü yazılan ön oyunla yeni kurulan Cumhuriyet'in kimliği haline getirilir. Yazar, destandaki oyun kişisi olan Oğuz'u, zamanı ve mekânı belli olmayan muğlak zaman diliminden çıkarır ve Oğuz çocuğun söylediklerine cevap verir;

\section{O $\breve{G} U Z$}

Bu yaman delikanl saydllar doğduğu günü,

Tüm 40 günün içinde tuttu dünyayı ünü.

Bu öz Türk ulusunu 40 gün emzirdi ana,

Daha süt istemedi, vermedi kimse ona.

O 40 günün içinde serpildikçe serpildi,

Yüzünü görmiyenler adını duydu, bildi.

Saçları pek karaydl, yüzü gök rengindeydi,

Belli Oğuz türklere gökten inme bir beydi. ${ }^{34}$

Oğuz Han mitolojinin tozlu sayfalarından çıkar, Cumhuriyet dönemi bir çocuğun sözlerine karşılık verir, böylece geçmişle bugün arasında bir paralellik kurulur. Böylelikle Aşkun, Oğuz

33 a. e., 8 .

34 a. e., s. 8 . 
Han'1 mitolojik zaman ve mekândan uzaklaştırarak gerçek zamana taşımakta ancak, mitin doğaüstü güçlerinden ve gerçeklikle bağdaşmayan özelliklerinden vazgeçmemektedir. Yazar, Oğuz Destanı'nın mitolojik ve doğaüstü olayların gerçekleştiği olay örgüsünü Cumhuriyet Dönemi'nde geçen ön oyunla geçmişle bugün arasında bir ilişki kurar. Yazar, Oğuz Destanı'nı konu edinen bu oyun ile yeni devletin şanlı bir soy kütüğüne kavuşmasına ve köken yaratma gerekliliğine katkıda bulunur.

Aşkun'un Oğuz Destanı oyununun kurgusunu resmi tarih yazımı etrafında şekillen köken miti çerçevesinde şekillendirme tercihinin bir benzeri Faruk Nafiz'in Akın adlı oyununda da görülür. Oyun, Orta Asya'da yağmur yağmamasından dolayı yaşanan kuraklığı bahane ederek Başbuğların İstemi Han'ı tahttan indirmeye çalışması, İstemi Han'ın bunu fark ederek Başbuğları cezalandırmasını ve sonra verimli topraklar bulmak için Türklerin başlattığı akınları anlatır. Faruk Nafiz Orta Asya'da geçen hikâyeye, Aşkun'un yaptığı gibi, Türkiye'de geçen bir ön oyun eklemiştir. Oyun, Talebe'nin sahnedeki büyük dünya haritasında, Türklerin Orta Asya'dan diğer bölgelere gerçekleştirdikleri akınları gösteren prolog sahnesiyle başlar. Talebe adlı oyun kişisi yapılan akınları anlatmaya başlar;

\title{
TALEBE
}

\author{
(...) İşte şu Ortaasya ... Türklerin anayurdu... \\ Türk ilk medeniyeti Altay-Uralda kurdu. \\ Sora, alıp sazını, resmini, heykelini, \\ Dolaştı baştanbaşa doğu, batı elini. \\ Bu oklar bize akın yollarını gösterir, \\ Bize yirmi bin yllın üstünden haber verir... \\ Şimdi siz dersiniz ki: "Peki, nasil olur da \\ Orda kalmak dururken dağıldık şurda, burda?" \\ Anlatsam uzun sürer, hem belki sıkar canı, \\ Bari canlandirayım sahnede bu destanı. \\ Bakın, niçin dağıldık Misırda, Hintte, Çinde? $?^{35}$
}

Talebe Türklerin akınlarından övgü dolu sözlerle bahsettikten sonra oyun başlar. Oyun kişisinin yazar tarafından Talebe olarak adlandırılması emekleyen ulus devletin tahayyül ettiği vatandaş tanımıyla birebir örtüşmektedir. Tek parti ideolojisi yeni kurulan devletin vatandaşlarının durmadan çalışmasını ve muasır medeniyetler seviyesine yükselmesi için bütün özeni ve gayreti göstermelerini istemektedir. Yazarın da oyun kişisi olarak Talebe’yi tercih etmesi bilgiye ve öğrenmeye hevesli vatandaşın vücut bulmuş halidir. Oyunun hikayesinde vurgulanan nokta, Başbuğların İstemi Han'a ihanetidir ve oyun Orta Asya'da geçmektedir. Yazarın eserine Türkiye'de geçen bir ön oyun eklemesi Türk Tarih Tezi'nin iddiasını, yeni kurulan devleti Orta Asya'yla ilişkilendirme çabasını destekleme amacı taşımaktadır. Yeni

35 Nafiz, Akın, 8 . 
devletin köken kurgusu ve bu kurgunun kendine meşru bir zemin arayışı, Faruk Nafiz'in oyununda adeta canlanmış gibidir. Yazarın resmi tarih yazımıyla birebir örtüşen söylemi tiyatro sanatına yaklaşımını da açıkça gözler önüne sermektedir.

Erken Cumhuriyet Dönemi tiyatro oyunlarında yer alan köken mitinin yanında, karşımıza sıklıkla çıkan bir diğer mit de medeniyet mitidir. Bu iki mitin anlatıları, birbirini tamamlayarak yeni kurulan devletin zeminini meşrulaştırır. Yeni kurulan devletin resmi tarih yazımı; akınlarla Orta Asya' dan dünyanın çeşitli yerlerine gelen Türklerin çoğu medeniyetin kurucusu olduklarını iddia eder. Sümer, Hitit ve Yunan gibi uygarlık tarihinin önemli medeniyetleri, tek parti ideolojisinin tarih yazımı stratejisi doğrultusunda Türklere mal edilir. Köklerini Orta Asya'da bulan Türkiye Cumhuriyeti Devleti, uygarlık tarihindeki önemli medeniyetlerle ilişki kurarak geçmişteki gücünü ispat etmenin ve böylece mevcut gücüne meşruiyet kazandırmanın peşine düşer. Bu bağlamda İsmet Ulukut'un Sümer Ülkerleri adlı eseri, medeniyet mitinin tiyatro oyunlarına yansımasına önemli bir örnektir. Yazar oyunun başında eserini "Türk tarihinin 3 perdelik bir görünüşü” olarak özetleyerek, Sümerlerin Türk olduğunu iddia eder. Oyunun özeti şöyledir; Sümer sitelerinin kendi içindeki savaşlarından dolayı, dışarıdan gelen Guti kavmi Sümerler'in başına geçer. Uzun yıllar Sümerleri yönetir. Uruk Valisi Utu-Kegal, Sümerler'in başında olan Guti kralı Tirigan'a başkaldırır. Bütün Sümer halkı Utu-Kegal'in etrafında toplanır. Sümerler Guti hâkimiyetinden kurtulur. İsmet Ulukut'un 1934 yılında yazdığı bu oyun, sadece Sümerlerin, Guti'ye karşı mücadelesini anlatmaz, oyun boyunca çeşitli karakterler tarafindan pek çok diyalogda Sümerlilerin Türk olduğu iddiası dile getirilir. Guti’lere karşı zafer kazanan Utu-Kegal'in sözleri buna örnektir;

\section{Utu- Kegal}

(...) Sümer, her soydan ulu Türk soyunun koludur,

Onu kurtarmak için can verenler uludur. ${ }^{36}$

Oyunda Türklerin Sümer topraklarına gelmeden önceki durumu, aşağıdaki sözlerle anlatılır;

\section{Utu- Kegal}

(...) Çamurların içinde, el, ayakla yürüyen,

Ağzile ot yiyerek yaşamayı sürüyen

O adamlar bilmemiş ne buğdayl, ekmeği,

Ylllarca sürünmüşler bilmeden giyinmeyi,

Adamdır diyemezsin, sürü sürü canavar.

Bataklıkta o yaban sürüyle karşılaştı.

Onları dağıtarak yurd edindi bu yeri,

Kolayca kurmamışlar gördüğünüz Sümeri.

Bilgi tohumlarını saçan büyük Türk soyu,

Yollar yapıp dă̆ıttı yer yer biriken suyu;

36 İsmet, Sümer Ülkerleri, 49. 
Bataklı̆̆ kuruttu. Arpa, buğday bitirdi.

Davarl, tohumları türk elinden getirdi, ${ }^{37}$

Yazar Sümerler'in Türk olduğu iddiasıyla da kalmaz, Türklerin Sümer kurulmadan önce medeniyetten uzak bir yaşam sürdüklerini belirtir ve o coğrafyanın yerli halkını canavar olarak nitelendirir. Yazar Sümerlerin Türk olduğu iddiasını, kendinden önceki bütün yaşamı yok sayacak bir dille eserine yansıtır. Sümer Ülkerleri'nde coğrafyanın yerlisini görme biçimi benzer şekilde Faruk Nafiz'in Özyurt oyununda da görülmektedir;

Akın

(...) Adam demek bu yaban kısmina doğru mudur?

Atlar gibi otlayan sürüye insan deme,

Duygusu dört olanların, lisanı kırk kelime.

Nasil lisan denilir kirk hecelik bir dile,

Bunlardan daha zengin, lisanca baykuş bile. ${ }^{38}$

Akın da benzer şekilde yerli insanların yaşam biçimleri küçümsemekle kalmayıp, burada yaşayan insanların duygularının neredeyse olmadığına ve konuştukları dile dair hakaret içeren sözler ifade eder. Yukarıdaki alıntının devamında Akın, buradaki insanların sevginin ne demek olduğunu bile bilmediklerini söyler. Türkler yine göç ettikleri topraklara medeniyet getiren bir güç olarak gösterilir. Nafiz, oyunun başında akıncılar sahneleriyle dünyadaki medeniyetin ışığının Türkler olduğunu açıkça ifade eder.

Bu bölümde incelediğimiz oyunların çoğunda olduğu gibi, Behçet Kemal'in Çoban adlı oyununun başında ve sonunda Cumhuriyet Dönemini anımsatan sahneler vardır. Oyunun olay örgüsü Türkler'e ait bir kahramanlık destanı olarak görünse de Behçet Kemal, oyunun ilk sahnesine Tarih adlı oyun kişisini koyarak köken ve medeniyet mitini yeniden inşa etmenin peşindedir. Ders çalışmaktan sıkılan çocuğun yanında bir anda beliren siyah şapkalı ve siyah pelerinli Tarih şu sözleri söyler;

\section{Tarih}

Tarih bu! masal değil, laf değil, roman dĕgil...

Tarih senin kitabin sen tarihin malisin

(...)ISte hayklrıyorum: daha büyük Türk benden;

Türkü gördüm ilk önce dünyaya gelince ben! ${ }^{39}$

Tarih adlı oyun kişisinin çocuğa bu nasihati, Türklerin tarihin başlangıcı olduğu iddiasının sonucudur. Yazar sadece yeni kurulan devletin köklerini bulmakla kalmaz, Türkleri tarihin

37 a. e., 36-37.

38 Nafiz, Özyurt, 17.

39 Kemal, Çoban, 5. 
başlangıç noktası olarak ilan eder. Oyunun ama hikayesi bir çobanın vatanı için mücadelesini anlatmaktadır; ancak, ön oyun, oyunun sonunda görünen Atatürk büstü görülmesi ve Gençliğe Hitabe'nin okunması, Behçet Kemal' in bu oyunu yazma motivasyonunun yeni yurttaşlara tarih ve köken bilincini aşılamak olduğunu göstermektedir. Tablo olarak bahsettiği Tarih ve Çocuk adlı karakterlerin sahneleri ve Çoban karakterinin ülkesi için mücadelesini anlatan hikâye arasında kurulan bağ eklektik bir halde kalır. Bunun sebebi, yazarın temel arzusunun; farklı zaman ve mekân kurgularıyla nitelikli bir tiyatro eseri çıkarmaktan ziyade ulusun gücünü göstermek olmasıdır. Tarih adlı oyun kişisinin ilk sahnedeki sözleri ile ortaya konan Türkler'in medeniyetin kurucu gücü olma hali, Bey adlı oyun kişisinin şu sözleriyle devam eder;

Bey

Türk kolu buraya geldiği zaman

Onlar daha tastan

Su içmeyi bilmiyorlardı bile

(...)Sanati, hakikati, ilmi, kahramanlığ

Dünyaya yaysin diye tanrı türkü yarattı ${ }^{40}$

Yine Türkler uygarlığı getiren ırk olarak gösterilir. Tanrı'nın yeryüzündeki gölgesi olarak temsil edilen Türk milleti, kendinden önceki insanlık tarihinin varlığını kabul etmez bir hale gelir. Oyunun sonuna doğru Tarih'in şu sözleri de bu durumu daha da açık hale getirir;

\section{Tarih}

(...)Benim doğduğum yer de türk gibi orta asya:

Biz ırkınla bir doğup büyüyen vatandaşız;

Küre, türk ve bir de ben.. Biz en eski üç başız.. ${ }^{41}$

Yazar, tarihi Türklerle birlikte Orta Asya'dan başlatmakla yetinmeyip, evrenin varoluşunun Türklerin varoluşu ile eş zamanlı gerçekleştiğini iddia eder. Yazar eserinde resmi tarih yazımını esas alarak yeni devletin ve ulusun gücünü ispat etmeye çalışır. Bu bağlamda Behçet Kemal'in Anayurt gazetesindeki şu sözleri, eserlerinde tek parti ideolojisiyle son derece paralel bir söylem benimsediğini kanıtlar niteliktedir;

Hedef, medeniyetin ön safidır, ileri!.. (...)

Iş̧̧i, dilci, tarihçi.. Fakat hep aynı nefer!

Her sefer başka kit'a emir alıp yürüyor...

Toplanın: Sirayl “O” bugün sirayı bizde görüyor;

40 a. e., 29-30.

41 a. e., 60. 


\section{Arş! Firça, kalem ve yay, süngü gibi ileri! \\ Başlıyor "güzel san'at kit'asi”"nin seferi! ${ }^{42}$}

Behçet Kemal'in bu sözleri, ortaya koyduğu eserlerinin niteliğini ve içeriğini açık bir şekilde özetlemektedir. Kemal, medeniyetin ilerleme kaydetmesi için, güzel sanatların bütün dallarında seferberlik ilan etmekte ve sanatçıları yeni kurulan Cumhuriyet' in neferleri olarak nitelendirmektedir. Bu bağlamda tek parti ideolojisinin Orta Asya üzerinden kurguladığı köken ve medeniyet mitinin, yukarıda incelediğimiz yazarların oyunlarında yer alması dönemi için hiç de olağan dışı bir şey değildir.

\section{Sonuç}

Erken Cumhuriyet Dönemi'nde tiyatroya yüklenen bu misyon sonucunda, tiyatro sanatı belirli estetik amaçlar etrafinda şekillenen bir sanat olmaktan ziyade, tek parti ideolojisinin amaçlarıyla şekillenen bir sanat olarak varlık gösterir. Kurucu kadrolar tarafından, Kemalist ideolojinin yaygınlaşması için izlenen, tiyatro sanatı, oyun yazımı ve gösterimlerin gerçekleşmesi konularındaki stratejiler, yeni Cumhuriyet' in kurumsallaşması ve halk tarafindan içselleştirilmesi için elzem konumdadır. Tiyatro aracılığıyla inşa sürecini hızlandırmaya çalışan tek parti ideolojisi, tiyatro sanatının estetik kaygılardan ziyade ulusal çıkarlar doğrultusunda biçimlendirilmesine yol açmıştır.

Sonuç olarak, yazarlar oyunlarının olay örgüsünü Orta Asya hikayelerini temel alarak kurgulasalar da oyunların başına ve sonuna eklenen sahnelerin içeriği Erken Cumhuriyet Dönemi'nde geçen sahnelerdir. Yazarlar kullandıkları bu ikili zaman ve mekân ile, geçmişle, yeni kurulan Cumhuriyet' in ilişkisini kurmak isterler. Kurgulanan mitsel uzam, beraberindeki Cumhuriyet'in temel doktrinlerine yapılan atıflar ve yeni devletin gücünü betimleyen sahneler, tiyatro eserlerindeki köken ve medeniyet mitini görünür kılar. Toplumsal, siyasal ve kültürel alanın inşasında önemli bir işlevi olan siyasal mitlerin izleri, incelenen oyunlarda köken ve medeniyet miti olarak karşımıza çıkmaktadır.

\footnotetext{
Hakem Değerlendirmesi: Dış bağımsız.

Çıkar Çatışması: Yazar çıkar çatışması bildirmemiştir.

Finansal Destek: Yazar bu çalışma için finansal destek almadığını beyan etmiştir.
}

Peer-review: Externally peer-reviewed.

Conflict of Interest: The author has no conflict of interest to declare.

Grant Support: The author declared that this study has received no financial support.

42 Behçet Kemal, “Güzel san'at kıtası”, Anayurt: Haftalık İlim ve Sanat Gazetesi 6 (1933), 5. 


\section{KAYNAKÇA / BIBLIOGRAPHY}

Aktar, Cengiz. "Osmanlı Kozmopolitizminden Avrupa Kozmopolitizmine Giden Yolda Ulus Parantezi”,

Modern Türkiye’de Siyasi Düşünce-Milliyetçilik. İstanbul: İletişim Yayınları, 2002.

Aşkun, Vehbi Cem. Oğuz Destanı. İstanbul: Milli Mecmua Matbaası, 1935.

Aydın, Suavi. Modernleşme ve Milliyetçilik. Ankara: Gündoğan Yayınları, 1993.

Cassirer, Ernst. Devlet Efsanesi-İnsan Üstüne Bir Deneme, çev. Necla Arat. İstanbul: Say Yayınları, 2005.

CHP. Halkevleri 1932-1935: 103 Halkevi Geçen Yillarda Nasıl Çalıştı. Ankara: 1935

Çeçen, Anıl. Halkevleri. Ankara: Gündoğan Yayınları, 1990.

Erbay, Fethi ve Erbay, Mutlu. Cumhuriyet Dönemi (1923-1938) Atatürk’ün Sanat Politikası. İstanbul: Boğaziçi Üniversitesi Yayınevi, 2006.

Firidinoğlu, Nilgün “Tanzimat’tan Erken Cumhuriyete Tiyatro ve Eğitim İlişkisi: Mektep Temsilleri (18961936)". Doktora Tezi, İstanbul Üniversitesi, 2015.

Hayri, Münür. “Bugünkü Manasiyle Tiyatro Nedir?”, Ülkü Halkevleri Mecmuası 18 (1934).

İsmet, A.. Sümer Ülkerleri. İstanbul: Ülkü Kitaphanesi, 1934.

Kadıoglu, Ayşe. "Milliyetçilik-Liberalizm Ekseninde Vatandaşlık ve Bireysellik", Modern Türkiye'de Siyasi Düşünce-Milliyetçilik. İstanbul: İletişim Yayınları, 2002.

Kalkan, Saim Kerim. "Cumhuriyet Devrinde Tiyatro Hareketleri ve Halkevleri” Yeni Türk 71 (1938).

Kemal, Behçet. Çoban. Ankara: Hakimiyeti Milliye Matbaası, 1933.

Kemal, Behçet. “Gönüllü Sanat”, Ülkü Halkevleri Mecmuası 23 (1935).

Kemal, Behçet. “Güzel san’at kıtası”, Anayurt: Haftalık İlim ve Sanat Gazetesi 6 (1933).

Koçak, Cemil. "Kemalist Milliyetçiliğin Bulanık Suları”, Modern Türkiye'de Siyasi Düşünce-Milliyetçilik.

İstanbul: İletişim Yayınları, 2002.

Mardin, Şerif. Türkiye’de Din ve Siyaset. İstanbul: İletişim Yayınları, 1991.

Nafiz, Faruk. Özyurt. Ankara: Hakimiyeti Milliye Matbaası, 1932.

Nafiz, Faruk. Akın. İstanbul: Devlet Matbaası, 1932.

Orkun, Hüseyin Namık. "Bir Oğuz Efsanesi”, Ülkü Halkevleri Mecmuası 34 (1935).

Öztürkmen, Arzu. Türkiye’de Folklor ve Milliyetçilik. İstanbul: İletişim Yayınları, 1998.

Siyavuşgil, Sabri Esat. “İstanbul'da Karagöz, Karagöz’de İstanbul”, Karagöz Kitabı, Derleyen Sevengül Sönmez, 104-118. İstanbul: Kitabevi, 2005.

Smith, Anthony D.. Millî Kimlik, çev. Bahadır Sina Şener. İstanbul: İletişim Yayınları, 2016.

Smith, Anthoy D.. Ulusların Etnik Kökeni, çev. Hülya Kendir, Sonay Bayramoğlu. Ankara: Dost Kitabevi Yayınları, 2002.

Şener, Sevda. Cumhuriyet'in 75. Yllında Türk Tiyatrosu. İstanbul: Türkiye İş Bankası Kültür Yayınları, 1999.

Şimşek, Sefa. Bir İdeolojik Seferberlik Deneyimi Halkevleri 1932-1951. İstanbul: Boğaziçi Üniversitesi Yayınevi, 2002.

Ünlü, Barıș. Türklük Sözleşmesi. Ankara: Dipnot Yayınları, 2018. 